\title{
The Effect of Experiential Marketing on Customer Satisfaction Through Experiential Value as Intervening of Variables on Xiaomi Smartphone User
}

\author{
Thamrin $^{1 *}$, Adrian Rahmana Aresa ${ }^{2}$ \\ 1, 2 Universitas Negeri Padang, Padang, Indonesia \\ *Corresponding author. Email: thamrin@fe.unp.ac.id
}

\begin{abstract}
This study aims to analyze and prove the effect of experiential marketing on customer satisfaction with experiential value as an intervening variable. In this study, 150 students were active or were still registered at Padang State University and used Xiaomi smartphone brands. The analytical method is used to prove the hypothesis is done by SEM (Structural Equation Model) analysis which is processed with Smart PLS. In accordance with the results of hypothesis testing it was found that experiential marketing had no effect on customer satisfaction with experiential value as an intervening variable on students of Xiaomi brand smartphone users at Padang State University.
\end{abstract}

Keywords: Experential Marketing, Experential Value \& Customer Satisfaction.

\section{INTRODUCTION}

Everycompanies will compete competitively in terms of creating and offering various types of new products with different innovations [1]. This has led to a race of smartphone manufacturers to launch the latest products, resulting in competition among smartphone industry players. Thus, the company's ability to influence smartphone user experience value to a certain extent will be determined by the experience marketing strategy created by the company. Intense competition in the smartphone industry has made the company begin to instill the concept of experiential value in positioning products to defeat competitors.

One of the communication tools that recently stole the attention of consumers is the Xiaomi smartphone. Where Xiaomi smartphone at the end of December 2018, its sales are able to lead the sales market, which is 1.7 million units. (tekno.kompas.com). Android smartphone users in Indonesia are now choosing alternative smartphone choices that have premium design and good performance and various features, but at an affordable price (tekno.kompas.com).

According to the 2018 Top Brand Index, Xiaomi smartphones are already quite developed in the market and are included in the category of the top 5 smartphone brands. While the 2019 Top Brand Index data, Xiaomi smartphone has ranked second. This indicates that in 2018 Xiaomi smartphones have started to demand and have started to develop. The following are smartphone data for 2018 and 2019 according to the 2018 and 2019 Top Brand Index[2].

Table 1. Top Brand Index Based on Market Share Smartphone Brands in Indonesia in 2018 - 2019

\begin{tabular}{|l|c|c|c|c|}
\hline \multirow{2}{*}{ Brand of Smartphone } & \multicolumn{2}{|c|}{$\mathbf{2 0 1 8}$} & \multicolumn{2}{c|}{$\mathbf{2 0 1 9}$} \\
\cline { 2 - 5 } & $\begin{array}{c}\text { Market Share } \\
(\boldsymbol{\%})\end{array}$ & $\begin{array}{c}\text { Market } \\
\text { Position }\end{array}$ & $\begin{array}{c}\text { Market Share } \\
(\boldsymbol{\%})\end{array}$ & $\begin{array}{c}\text { Market } \\
\text { Position }\end{array}$ \\
\hline Samsung & 48.60 & Top & 45.80 & Top \\
\hline Oppo & 11.20 & Top & 16.60 & Top \\
\hline Xiaomi & 5.50 & - & $2: 30$ p.m. & - \\
\hline Lenovo & 4.50 & - & 4.50 & - \\
\hline Nokia & 3.70 & - & 3.70 & - \\
\hline Other Brands & 26.50 & - & 15.10 & - \\
\hline
\end{tabular}

From the data of Indonesia's Top Brand Index in 2018, Samsung looks at the top of the list, which is $48.6 \%$, Oppo is second, Xiaomi is third and Lenovo is fourth. While Xiaomi in the 2018 Top Brand Index includes the top 5 smartphone brands in
Indonesia. Then, in Indonesia's Top Brand Index data for 2019, Samsung experienced a slight decline but remained in first place at $45.8 \%$, Oppo ranked second and Xiaomi ranked third. Here Xiaomi proves that the smartphones they sell are able to compete well in Indonesia. Even so the share of 
smartphones can still be taken over by competing smartphones in the future so it is very important for Xiaomi to create consumers who are more committed to them.

The high sales of Xiaomi brand smartphones are due to the high value of customer satisfaction in using Xiaomi brand smartphones. According to [3] customer satisfaction shows the feeling of pleasure and joy felt by consumers in using a product brand that is formed because of the match between the level of importance or expectations they have with the reality felt after using a brand.

[4] state that customer satisfaction can be influenced by a number of variables including experiential marketing and experiential value. The experience value that marketers tell consumers creates interest and emergence of needs, thus encouraging them to buy and use a brand. When all desires and expectations can be fulfilled after using a particular product brand, then a positive experience in using (experiential value) and satisfaction will be formed in consumers.

Experience value is one of the critical successes in influencing the attitude of usage towards mobile applications [5]. The tightness of competition also forces companies to innovate and design strategies in instilling positive experiential values in the minds of consumers. [5] define value experiences as consumers' assessment of service use through efficiency, excellent service, aesthetic, and playfulness in using services. The company can influence the value experience to a certain extent will be determined by the experiential marketing strategy created by the company.

Experiential value has been defined as perceptions and interactions involving direct use or appreciation of goods and services. This interaction provides the basis for relativistic preferences held by the individuals involved [6] [7]. Experiential value offers extrinsic and intrinsic benefits [8] [6] This broadens the traditional extrinsic-intrinsic conceptualization of experiential value including the activity dimension. Reactive or passive value comes from understanding consumer appreciation for objects or consumption experiences. Active or participatory value, on the other hand, shows a high collaboration between consumers and marketing entities.

Experiential Marketingis customer recognition of marketing experience that consists of five dimensions, namely sense, feel, think, act, relate [9]. This makes smartphone users not only judge product performance but also the entertainment that a product can provide to it. Experiental Marketing creates an impression of consumer experience, where consumers are interested in using products by looking at the satisfaction of others who use similar products first. This will provide benefits for producers to know the development of products on the market and also to increase long-term loyalty and provide a different experience with other companies and not forget when using the product that was bought. The company will engage customers emotionally and psychologically in using the products offered by the company. Experiential value is the opinion of consumers starting from the beginning of the purchase until the usage, then the benefits of the product purchased by consumers are obtained. Consumer knowledge in the use of products will give an idea of satisfaction.

Through sense experience, consumers will be able to develop logical experience and then they use logical experience to shape personal in considering differentiating products and services experienced by them or the experience phase (pre-purchase, purchase and after purchase) [10]. Feel experience is called emotions, moods and feelings of customers obtained from consuming products and services [11] [12]. With positive feelings generated in the consumption process, consumers develop positive emotions [13]. [13] experiential act allows consumers to develop experiences related to the consumer's physical body, behavior and lifestyle as well as experiences gained from social interactions with others. The purpose of act experience is to give an impression of behavior patterns and lifestyles, as well as to enrich patterns of social interaction through the strategies carried out [14]. [13], Experiential Think stimulates the customer's creative thinking in developing new ideas or thinking about a company or its products. The purpose of think experience is to encourage consumers to be interested and think creatively so that they may be able to produce a re-evaluation of the company and the brand [14]. Relate experience is one way to form or create a community of customers with communication [15]. Telling experience allows consumers to build their relationships with social communities through the process of buying and consuming products or services [16]. The purpose of relate experience is to connect these consumers with the culture and social environment that is reflected by the brand of a product [14].

Based on the problem formulation that has been described above, the research objectives are:

1. Prove the effect of experiential marketing on experiential value on Xiaomi Smarphone user students at Padang State University.

2. Prove the effect of experiential value on customer satisfaction on Xiaomi Smartphone users at Padang State University.

3. Prove the effect of experiential marketing on customer satisfaction on Xiaomi Smartphone users at Padang State University.

Proving the effect of experiential marketing on customer satisfaction through experiential value as an intervening variable on students of Xiaomi Smartphone users at Padang State University. 


\subsection{The Effect of Experiential Marketing on Experiential Value}

[17][18] found that experiential marketing had a positive effect on experiential value on Blackberry products. The results obtained occur because the experience told by marketers in the form of sense experience, feel experience, think experience, act experience and relate experience can be proven by consumers when they have used a product or service, the proof is seen from the value and benefits provided when consumers use the product. Convenience in using shows that experiential value has formed in the consumer's users.

[19] revealed that experiential marketing had a positive and significant effect on experiential value in using smartphones in the city of Denpasar. The marketer's team experience that was told to the user, proved to be appropriate, thus providing a useful experience for smartphone users. Positive values and perceived benefits encourage consumers to include these positive experiences with others so as to create good experiential value. Similar results were also obtained by [20] who found that experiential marketing had a positive effect on experiential value in using Wardah brand lipstick. The situation occurs when female consumers who use wardah lipstick have felt the value and benefits of the product, which of course will be adjusted to the story or experience provided by marketers before buying and using lipstick. Positive experiences that are felt will encourage consumers to retell their experiences to others.

\subsection{The Effect of Experiential Value on Customer Satisfaction}

[21] found that experiential value has a positive and significant effect on customer satisfaction in using the Samsung brand android. The comfort felt by consumers in using them shows the satisfaction felt when using a smartphone, especially the Samsung brand. Encourages users to share it with others.

[20] found that experiential value has a positive and significant effect on customer satisfaction in using Wardah brand lipstick. The results obtained are due in general to female consumers who use wardah lipstick feel positive benefits. Where these benefits are in accordance with the wishes or expectations of each user. Conformity between expectations and the reality of using products shows a sense of satisfaction that arises in female consumers in using Wardah brand lipstick.

\subsection{The Effect of Experiential Marketing on Customer Satisfaction}

[20] found that experiential marketing had a positive and significant effect on customer satisfaction in using a product brand. Stories of positive experiences about the use of products by marketers, felt appropriate by consumers. Where all the desires expected by consumers can be fulfilled so that the expected satisfaction can be realized. Satisfaction also shows the feeling of joy and pleasure in using a brand, satisfaction will also encourage consumers to tell the positive experiences they feel in using certain brand products to those closest to them.

[19] found that experiential marketing has a positive effect on customer satisfaction in using a product brand. The results obtained occur because everything expected by consumers in using a brand can be realized in the form of reality. Perceived satisfaction will create a higher motivation in consumers to re-use the brand and try to recommend the brand of products that have been consumed to others.

Consistent results were also obtained by [17][18] who found that experiential marketing had a positive effect on customer satisfaction. When consumers feel happy, happy and comfortable using a brand. Showing all the desires or expectations that consumers have before using a brand can be realized, the situation shows the satisfaction felt by consumers in using a brand of product or service.

\subsection{The Effect of Experiential Marketing on Customer Satisfaction Through Experiential Value as an Intervening Variable for Xiaomi Smartphone Users at Padang State University}

[21] found that experiential marketing has a positive effect on customer satisfaction through experiential value as an intervening variable. The results obtained indicate that when consumers will buy a product, the marketer (sales) will give a positive story about the brand of the product to be purchased, after the purchase and utilization of the product is done, consumers will compare the value or benefits they receive when using the product with a sales story, when conformity occurs then satisfaction and experiential value emerge. Given the satisfaction felt in using a product will be retold to others, so that suggest also use the same product brand.

[20] found that experiential marketing has a positive effect on customer satisfaction through experiential value as an intervening variable. These findings reinforce the theory that the conformity of desires with the perceived performance in using a brand will create satisfaction. Feeling satisfied in using a brand shows the role of sales in providing positive experiences to consumers in using a brand quite effectively, the satisfaction that is felt will also encourage consumers to re-share their positive experiences with others around them.

\section{METHODS}

\subsection{Type Research}

Researchthis is classified as a causative descriptive study. Causative research shows the 
direction of the causal relationship between the independent variable and the dependent variable. This study aims to see how much the independent variable influences the dependent variable. Judging from the purpose of the variable to be studied is to see the causal relationship of the phenomenon or problem solving that will be examined to see how the Effect of Experiential Marketing Dimensions on Experiential Value on XIAOMI Smartphone users at Padang State University

\subsection{Place and Time Research}

Research on the Influence of Experiential Marketing Dimensions on Experiential Value on XIAOMI Smartphone users at Padang State University While the research time was September to October 2019 in Padang City.

\subsection{Population and Sample}

In this study, the population were students of Padang State University who had or were currently using smartphones, while the population were several Xiaomi brand smartphone users at Padang State University, totaling 150 respondents. The sampling method used in this study was using purposive sampling method, which is a sampling technique used by researchers if researchers have considerations or are based on certain criteria. The sampling criteria in this study are:

a. Aged over 17 years, respondents aged over 17 years are assumed to always be critical of the analysis so that it is more rational and objective in assessing things.

b. Padang State University students who have used Xiaomi smartphones at Padang State University.

c. The status of the original student or active at Padang State University, the reason the author chose respondents at Padang State University because the author wants to know the attitudes of consumers at Padang State University in using the XIAOMI smartphone.

\section{RESULTS AND DISCUSSION}

\subsection{Descriptive General of Respondents}

After all data and information have been collected, the data processing can be carried out immediately. The data processing is carried out with the help of Smart PLS. In accordance with the results of the processing can be narrated descriptive general respondents who participated in this study as shown in Table 2 below.

In Table 2, it can be seen that the majority of respondents are male-gendered, amounting to 77 people or $51.33 \%$ while the remaining respondents who are female-sexed amounted to 73 people or 48.67. Besides that, from the results of a survey that has been carried out it is known that the majority of respondents have an age level between 21 years to 23 years which amounted to 94 people or $62.67 \%$ of the total respondents while the respondents with the lowest age level are those who have an age over 25 years which amounts to 8 people or $5.33 \%$ of the total respondents. Based on the descriptive description of respondents it can be concluded that in general respondents who participated were dominated by respondents who were male and relatively young.

Table 2. Descriptive General of Respondents

\begin{tabular}{|c|c|c|}
\hline $\begin{array}{c}\text { Descriptive } \\
\text { Respondents }\end{array}$ & amount & Percentage \\
\hline \multicolumn{3}{|l|}{ Gender } \\
\hline Male & 102 & 68.00 \\
\hline Girl & 48 & 32.00 \\
\hline \multicolumn{3}{|l|}{ Age } \\
\hline $18-20$ years & 33 & 10:00 PM \\
\hline $21-23$ years & 98 & 65.33 \\
\hline 24-25 years & 19 & 12.67 \\
\hline \multicolumn{3}{|l|}{ Faculty } \\
\hline The economy & 37 & 24.67 \\
\hline Language and Art & 9 & $6: 00$ \\
\hline Social Sciences & 20 & 13.33 \\
\hline Sports Science & 27 & $18: 00$ \\
\hline Education & 22 & 14.67 \\
\hline Mathematics and & & \\
\hline Natural Sciences & 12 & 8.00 \\
\hline Technique & 14 & 9.33 \\
\hline Tourism and & 9 & $6 \cdot 00$ \\
\hline \multicolumn{3}{|l|}{ Using experience } \\
\hline Ever & 128 & 85.33 \\
\hline Has never been & 22 & 14.67 \\
\hline \multicolumn{3}{|l|}{ Long Using Xiaomy } \\
\hline$<1$ year & 79 & 52.67 \\
\hline 12 years old & 41 & 27.33 \\
\hline$>3$ years & 30 & 8:00 p.m. \\
\hline \multicolumn{3}{|l|}{ Xiaomi Type Used } \\
\hline Redmi Note 8 & 33 & 10:00 PM \\
\hline Mi Max 2 & 10 & 6.67 \\
\hline Redmi 8 & 34 & 22.67 \\
\hline Redmi 6 Pro & 5 & 3.33 \\
\hline Redmi 8A & 18 & 12.00 \\
\hline Pocophone F1 & 9 & $6: 00$ \\
\hline Redmi 4A & 9 & $6: 00$ \\
\hline Redmi 6A & 14 & 9.33 \\
\hline Redmi Note 4 & 6 & 4.00 \\
\hline Redmi Note 7 & 3 & 2.00 \\
\hline Redmi Note 8 Pro & 7 & 4.67 \\
\hline Redmi Note 8T & 1 & 0.67 \\
\hline Total & 150 & 100 \\
\hline
\end{tabular}

Based on the results of a survey that has been done, it appears that the majority of respondents are students from the Faculty of education, amounting to 27 people or $18 \%$ of the total respondents while the respondents with the lowest frequency are those who come from the engineering faculty, amounting to 9 people or $6 \%$ of total respondents. In addition, all respondents who participated in this study had 
used Xiaomi brand smartphones with various types. Based on the general descriptive results of the respondents it can be seen that in general students participating in this study have relatively different faculties.

If observed from Xiaomi smartphone types, it is known that most respondents use Xiaomi Redmi Note 8 type smartphones, amounting to 56 people or $37.33 \%$ while respondents who use Xioami Redmi 6 Pro type smartphones have the least amount or frequency of 12 people or $8 \%$ of total of all respondents. Based on the descriptive statistical description, it can be seen that each student made as a respondent uses a Xiaomi brand smartphone with relatively different types and specifications. In this case students generally adjust smartphone types and specifications to their individual needs.

\subsection{SEM (Structural Equation Model) Testing}

In order to prove the truth of the hypothesis the researcher uses structural equation model analysis which is processed using Smart PLS. In general, the stages of data analysis carried out are as follows:

\subsubsection{Analysis Outer model}

Table 3. Outer Loading Testing Results Continued

\begin{tabular}{|l|c|c|c|}
\hline $\begin{array}{c}\text { Statement } \\
\text { Items }\end{array}$ & $\begin{array}{c}\text { Customer } \\
\text { satisfaction }\end{array}$ & $\begin{array}{c}\text { Experiential } \\
\text { marketing }\end{array}$ & $\begin{array}{c}\text { Experiential } \\
\text { value }\end{array}$ \\
\hline EVA1 & & & 0869 \\
\hline EVA2 & & & 0831 \\
\hline EVA3 & & & 0.778 \\
\hline EVA4 & & & 0732 \\
\hline EVA5 & & & 0849 \\
\hline EVA6 & & & 089 \\
\hline EVA7 & & & 0.739 \\
\hline EVA8 & & & 0.779 \\
\hline EVA9 & & & 0701 \\
\hline EVA10 & & & 0.808 \\
\hline CS1 & 0848 & & \\
\hline CS2 & 0.886 & & \\
\hline CS3 & 0.904 & & \\
\hline CS4 & 0.860 & & \\
\hline EM1 & & 0815 & \\
\hline EM2 & & 0.794 & \\
\hline EM3 & & 0704 & \\
\hline EM4 & & 0.705 & \\
\hline EM5 & & 0.774 & \\
\hline EM6 & & 0824 & \\
\hline EM7 & & 0.801 & \\
\hline EM8 & & 0.801 & \\
\hline EM12 & & 0.778 & \\
\hline EM14 & & 0.779 & \\
\hline EM15 & & 0846 & \\
\hline EM16 & & 0.913 & \\
\hline EM17 & & 0877 & \\
\hline EM18 & & 0867 & \\
\hline EM19 & & 0869 & \\
\hline
\end{tabular}

According to [22] outer loading testing aims to determine the accuracy of the selection of statement items that support each variable. In testing the validity of each statement item is determined from the loading factor owned by each statement item that is worth $\geq 0.50$ while statement items that do not meet the requirements are eliminated from the data processing stage. Based on the results of the tests that have been carried out, a summary can be seen in Table 3 above.

Based on the results of outer model testing that has been done, it appears that all statement items used in measuring the research variables that make up the research model are declared appropriate because they already have a factor loading above or equal to 0.50 . Therefore all valid or precise statement items can continue to be used in the further data analysis stage.

\subsubsection{Construct Reliability and Validity Testing}

The construct reliability and validity test aims to find out the accuracy and reliability of each statement item that supports each variable. According to [23] a variable must have a Cronbach's Alpha value $\geq 0.70$, in addition to that a variable is also stated precisely when it has a composite reliability value $\geq 0.70$ and an Average Extracted (AVE) value $\geq 0.50$. Based on the results of the reliability testing that has been done, a summary of the results is shown in Table 4 below:

Table 4. Construct Reliability and Validity Test Results

\begin{tabular}{|l|c|c|c|}
\hline & $\begin{array}{l}\text { Cronbach's } \\
\text { Alpha }\end{array}$ & $\begin{array}{l}\text { Composite } \\
\text { reliability }\end{array}$ & AVE \\
\hline Customer_Satisf & 0889 & 0.929 & 0.765 \\
\hline Experiential_Ma & 0.962 & 0.966 & 0.654 \\
\hline Experiential_Val & 0.948 & 0.946 & 0.638 \\
\hline
\end{tabular}

Based on the test results, it is known that the customer satisfaction variable has a Cronbach's Alpha coefficient of 0.898 . The Cronbach's Alpha value obtained is above or equal to 0.70 , besides that the customer satisfaction variable reliability is also strengthened by a composite reliability value of 0.929 or has been above the standard value of 0.70 . Besides in the variable reliability testing stage also obtained Average Extracted value of 0.765 which is far above the standard value of 0.50 so it can be concluded that the customer satisfaction variable has been supported by reliable statement items, so that it can continue to be used in the further data analysis stages.

In accordance with the test results it is known that the experiential marketing variable has a Cronbach's Alpha coefficient of 0.962. The Cronbach's Alpha value obtained is above or equal to 0.70 , in addition to the variable reliability 
customer satisfaction is also strengthened by the composite reliability value of 0.966 or has been above the standard value of 0.70 . Besides in the variable reliability testing stage also obtained Average Extracted value of 0.654 which is far above the standard value of 0.50 so it can be concluded that the experiential marketing variable has been supported by a reliable statement item, so that it can continue to be used into further data analysis stages.

In the construct reliability testing phase, it is known that the experiential value variable has a Cronbach's Alpha coefficient of 0.948. The coefficient value obtained is far above the standard 0.70. Besides that the reliability variable of customer satisfaction is also strengthened by the composite reliability value of 0.946 or has been above the standard value of 0.70 . Besides in the variable reliability testing stage also obtained Extracted leverage value of 0.638 which is far above the standard value of 0.50 so it can be concluded that the experiential value variable has been supported by a reliable statement item, so that it can continue to be used into the stages of further data analysis.

\subsection{Determinant Validity Testing}

[23] revealed that the determinant validity test was carried out by observing the correlation coefficient values owned by each variable. The higher the determinant validity value, the more precise the analysis model used. Based on the results of data processing that has been done, a summary can be seen in Table 5 below:

Table 5. Discriminant Validity Test Results

\begin{tabular}{|l|c|c|c|}
\hline & $\begin{array}{c}\text { Cust- } \\
\text { sat }\end{array}$ & $\begin{array}{c}\text { Exp- } \\
\text { mark }\end{array}$ & $\begin{array}{c}\text { Exp- } \\
\text { Val }\end{array}$ \\
\hline Customer_Satisfaction & 0875 & & \\
\hline Experiential_Marketing & 0.628 & 0.809 & \\
\hline Experiential_Value & -0.124 & $-0,134$ & 0799 \\
\hline
\end{tabular}

Based on the results of determinant validity testing, it can be seen that the highest correlation coefficient value is owned by customer satisfaction which is 0.875 , followed by experiential value which has a correlation coefficient of 0.799 . The lowest correlation coefficient value is owned by experiential marketing variable that is equal to 0.809 , thus the value of the correlation coefficient formed has been above 0.70 so it can be concluded that the research variables used in this study will form a fit or appropriate analysis model.

\subsection{Analysis Heterotrait-Monotrait Ratio (HTMT)}

Heterotrait-Monotrait Ratio analysis is useful to ensure that each research variable used does not contain a high serial correlation. A variable is declared free from the symptoms of Heterotrait-
Monotrait Ratio when it has a correlation coefficient below 0.85 [22]. Based on the results of the tests that have been carried out, a summary can be seen in Table 6 below:

Table 6. Heterotrait-Monotrait Ratio (HTMT) Test Results

\begin{tabular}{|l|l|l|l|}
\hline & $\begin{array}{l}\text { Cust- } \\
\text { sat }\end{array}$ & $\begin{array}{l}\text { Exp- } \\
\text { mark }\end{array}$ & $\begin{array}{l}\text { Exp- } \\
\text { Val }\end{array}$ \\
\hline Customer_Satisfaction & & & \\
\hline Experiential_Marketing & 0.696 & & \\
\hline Experiential_Value & 0.096 & 0.105 & \\
\hline
\end{tabular}

In accordance with the results of the tests that have been done, it can be seen that each research variable to be analyzed has a correlation coefficient value below 0.850 so that it can be concluded that the analysis model used in the study has been freed from the symptoms of Heterotrait-Monotrait Ratio therefore further stages of data analysis can be do it soon.

\subsection{Inner Model Test Results}

The testing of the inner model aims to ensure that the structural framework model which is a combination of several sub-structures is declared appropriate. The inner model testing is done by using the coefficient of determination analyst (R2) based on the results of the testing that has been done, the summary is shown in Table 7 below:

Table 7. Determination Coefficient Test Results

\begin{tabular}{|l|c|c|}
\hline & R Square & $\begin{array}{c}\text { R Square } \\
\text { Adjusted }\end{array}$ \\
\hline Customer_Satisfaction & 0825 & 0822 \\
\hline Experiential_Value & 0.018 & 0.011 \\
\hline
\end{tabular}

Based on the results of testing the coefficient of determination can be seen that the structural model is formed, supported by two sub-structures namely the effect of experiential marketing on customer satisfaction, while the second model is an analysis that shows the influence of experiential marketing on experiential value.

In the first sub-structure model the coefficient of determination is obtained by 0.825 . The coefficient values indicate that experiential marketing and experiential value have a variety of contributions to encourage changes in customer satisfaction by $82.50 \%$ while the remaining $17.50 \%$ is influenced by other variables not used in the current research model.

In the second sub-structure model, it can be seen that the coefficient of determination obtained in the test is 0.018 , the coefficient value shows that experiential marketing is only able to provide variations in contributing to changes in experiential value variables perceived by consumers of Xiaomi 
smartphone users in Padang by $1.8 \%$ while the remaining $98.20 \%$ is explained by other variables not used in the current research model.
After merging the two sub-structures a structural model can be made as shown in Figure 1 below:

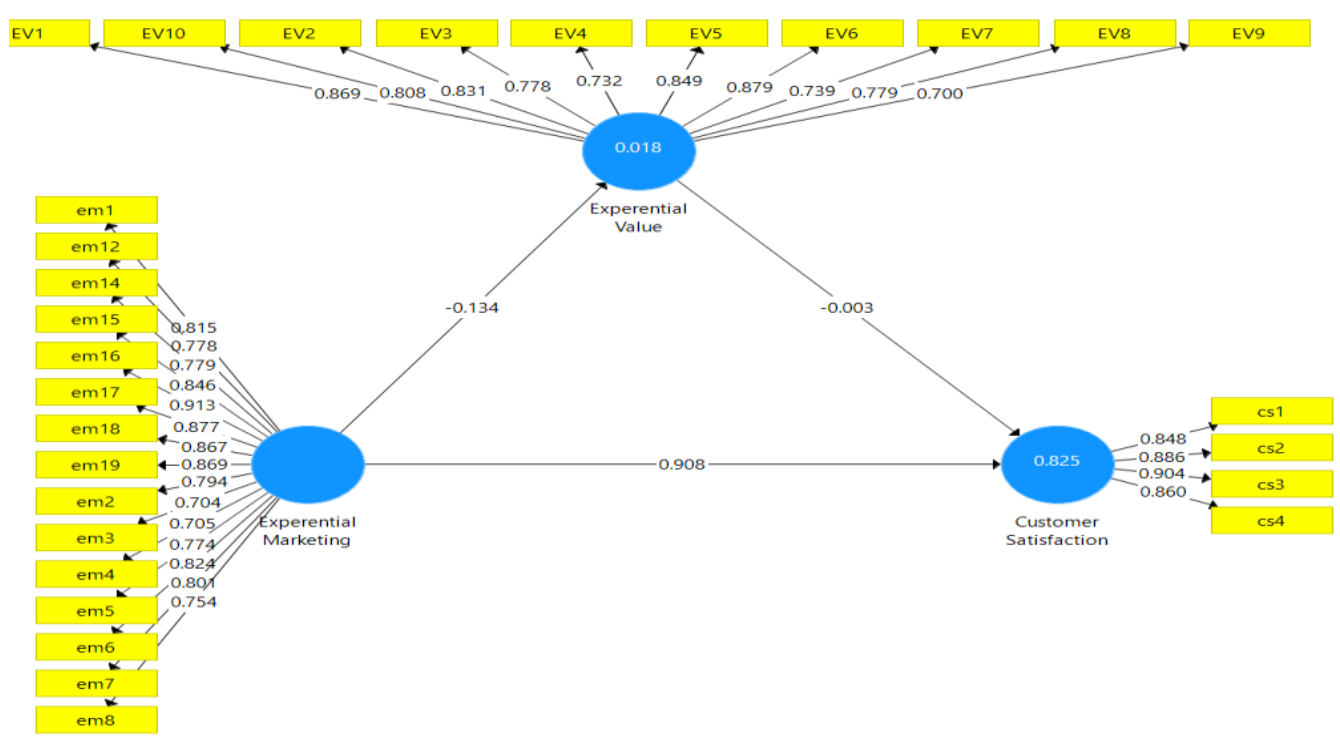

Figure 1. Structural Model

In accordance with the structural framework model formed by the sub-structure model that shows the effect of experiential marketing with experiential value is a fit model, while the model that shows the influence of experiential marketing on customer satisfaction with experiential value as an intervening variable tends to not fit, however the data analysis stage further can still be carried out.

\subsection{Hypothesis Testing Results}

After each item supporting the statement of variables is declared appropriate and reliable and has formed a fit model, the hypothesis testing stage can be carried out. In this study hypothesis testing was carried out using two stages namely:

\subsubsection{Testing the Direct Effect (Direct Effect)}

[24] testing the direct effect shows the relationship between the independent variable and the dependent variable without being mediated by other variables. Based on the results of tests that have been carried out using the help of the Smart PLS program, a summary of the results can be seen in Table 8 below:

Table 8. Summary of Direct Effect Testing Results

\begin{tabular}{|l|c|c|c|c|c|}
\hline & $\begin{array}{c}\text { Original Sample } \\
(\mathbf{O})\end{array}$ & $\begin{array}{c}\text { Sample } \\
\text { Mean (M) }\end{array}$ & $\begin{array}{c}\text { Standard } \\
\text { Deviation } \\
(\text { STDEV) }\end{array}$ & $\begin{array}{c}\text { T Statistics }(\mid \\
\text { O / STDEV |) }\end{array}$ & $\begin{array}{c}\text { P } \\
\text { Values }\end{array}$ \\
\hline EM -> CS & 0908 & 0.905 & 0.024 & 38,523 & 0,000 \\
\hline EM-> EV & $-0,134$ & -0.127 & 0.150 & 0888 & 0.375 \\
\hline EV -> CS & -0.003 & -0.002 & 0.046 & 0.056 & 0.956 \\
\hline
\end{tabular}

Based on the results of statistical tests that have been seen it can be seen that the experiential value variable has a path coefficient of 0.908 , the coefficient value is statistically proven with a $\mathrm{P}$ value of 0.000 . At the stage of statistical analysis is carried out using a 5\% confidence level. The results obtained show that the P-value of 0.000 is far below the $5 \%$ confidence level, the decision is Ho rejected and $\mathrm{H} 1$ accepted so that it can be concluded that experiential marketing has a positive effect on customer satisfaction of Xiaomi brand smartphone users at Padang State University.

In the second statistical testing stage, it is known that the magnitude of influence between experiential marketing on experiential value is 0.134 , the coefficient value is statistically proven with a P-value of 0.375 . At the stage of data analysis, the confidence level is 0.05 . The results obtained show that the P-value of 0.275 is far above the 0.05 error level, the decision is Ho is accepted and $\mathrm{H} 2$ is rejected so it can be concluded that 
experiential marketing does not significantly influence the experiential value perceived by students of Padang State University.

At the stage of statistical testing it is also known that the magnitude of the effect between experiential value on customer satisfaction is 0.003 . The coefficient value is statistically proven with a P-value of 0.956 . At the stage of statistical analysis done using a 5\% confidence level. The results obtained show that the $\mathrm{P}$-value of 0.956 is far above the $5 \%$ confidence level, so the decision is Ho accepted and $\mathrm{H} 1$ is rejected, so it can be concluded that experiential valuation does not have a positive effect on customer satisfaction of Xiaomi brand smartphone users at Padang State University.

The results obtained show the higher marketing experience delivered by marketers (mobile marketing), the experience of consumers to obtain value and benefits in using Xiaomi smartphone brands also has increased. The results obtained are in line with Keller (2015) which states that customer satisfaction can be influenced by a number of variables including brand image, brand reputation, ease of use and so on. In addition, the findings obtained at the first hypothesis testing stage are also supported by Irawan's research
(2017) which states that experiential marketing is not a variable that influences the formation of customer satisfaction.

At the stage of statistical testing it is also known that the magnitude of influence between experiential value on customer satisfaction is equal to 0.195 . the coefficient value is proven statistically with a P-value of 0.232 . At the stage of statistical analysis done using a 5\% confidence level. The results obtained indicate that the $\mathrm{P}$-value of 0.232 is far above the $5 \%$ confidence level, the decision is Ho accepted and $\mathrm{H} 1$ is rejected, so it can be concluded that experiential value does not have a positive effect on customer satisfaction of Xiaomi brand smartphone users at Padang State University.

\section{Indirect Effect Testing (Indirect Effect)}

The indirect effect test is intended to ensure that the independent variables used in this study have an influence on the dependent variable after being mediated by a particular variable. Based on the results of testing the indirect effects that have been carried out, a summary can be seen in Table 9 below:

Table 9. Summary of Tests on Indirect Effects

\begin{tabular}{|l|c|c|c|c|c|}
\hline & $\begin{array}{c}\text { Original } \\
\text { Sample (O) }\end{array}$ & $\begin{array}{c}\text { Sample Mean } \\
(\mathbf{M})\end{array}$ & $\begin{array}{c}\text { Standard } \\
\text { Deviation } \\
\text { (STDEV) }\end{array}$ & $\begin{array}{c}\text { T Statistics (| } \\
\text { O / STDEV |) }\end{array}$ & $\begin{array}{c}\text { P } \\
\text { Values }\end{array}$ \\
\hline EM -> EV -> CS & 0,000 & 0.003 & 0.009 & 0.038 & 0.970 \\
\hline
\end{tabular}

Based on the summary of test results, it can be seen that the amount of influence formed between experiential marketing on customer satisfaction through customer value as an intervening variable is 0,000 . The path coefficient value obtained is strengthened with a probability value of 0.970 . The results obtained show that the P-value of 0.970 is far above the $5 \%$ confidence level, the decision is $\mathrm{Ho}$ accepted and $\mathrm{H} 4$ is rejected so it can be concluded that experiential marketing has no effect on customer satisfaction through experiential value as an intervening variable in students at Padang State University using Xiaomi smartphones with various types.

The results obtained at the fourth hypothesis testing stage are in line with Keller (2015) which states that customer satisfaction can be influenced by a number of variables including brand image, brand reputation, ease of use and so on. In addition, the findings obtained at the first hypothesis testing stage are also supported by Irawan's research (2017) which states that experiential marketing is not a variable that influences the formation of customer satisfaction. Other consistent findings were also obtained by Hafid (2018) who stated that the satisfaction felt by consumers in using a smartphone is not only influenced by experiential marketing but can also be influenced by other variables such as brand image, brand reputation to brand love.

\section{CONCLUSION}

Based on the analysis and discussion of the results of hypothesis testing that have been carried out, it can be submitted several important conclusions which are answers to the problems discussed in this study, namely:

1. Experiential marketingpositive and significant effect on customer satisfaction of Xiaomi brand smartphone users at Padang State University.

2. Experiential marketingno significant effect on experiential value perceived by students of Padang State University.

3. Experiential value no significant effect on customer satisfaction of Xiaomi brand smartphone users at Padang State University.

4. Experiential marketing no significant effect on customer satisfaction through experiential value as an intervening variable on students at Padang State University who use Xiaomi smartphones with various types. 


\section{RESEARCH LIMITATIONS}

In accordance with the results of testing the hypotheses that have been done, there are still a number of hypotheses that cannot be proven. This happens because of the limitations that researchers have. Some of these limitations include:

1. In this study the respondents used were not diverse namely students, thus affecting the accuracy of the accuracy of the data obtained at the stage of hypothesis testing.

2. There are still a number of variables that allegedly also affect customer satisfaction that have not been used in this study such as brand awareness, brand image, brand reputation and so on.

\section{SUGGESTION}

Based on the results of hypothesis testing that has been done, it can be submitted several suggestions that can be useful for companies and distributors of Xiaomi smartphones in the city of Padang, namely:

1. In order to increase the value of experiential marketing to the satisfaction of Xiaomi smartphone users, suggestions are made:

a. For smartphone manufacturers, the Xiaomi brand is expected to carry out a product innovation process to make Xiaomi a highvalue trademark in the user's view. In addition, the innovations made by Xiaomi can create a more elegant Xiaomi smartphone design that will increase confidence and user satisfaction when using Xiaomi smartphones, especially for students at Padang State University.

b. Users are advised to buy Xiaomi smartphones that fit their needs, so that when used, the values and benefits obtained will increase the value of user satisfaction, especially students at Padang State University.

c. Distributors who sell Xiaomi smartphones are expected to continue to improve service to customers, so they feel comfortable and more satisfied to buy Xiaomi smartphone brands

2. In order to encourage the formation of customer value that affects increased customer satisfaction it is recommended:

a. Xiaomi smartphone manufacturers are expected to continue conducting surveys to customers to find out their needs, so that when the innovation is carried out it can produce Xiaomi smartphone variance in accordance with the features needed so that the desires or plans expected by users after using a smartphone can be fulfilled.

b. Producers are expected to continue to study the changing tastes of smartphone users and adjust these tastes through more interesting features in each Xiaomi smartphone variance, so there is comfort because customers feel all the hopes or desires expected before using a smartphone can be fulfilled

c. Manufacturers are expected to provide additional features that can be downloaded through the App store so that the needs that arise in the user when using Xiami can be met and create a feeling of joy and joy when using a Xiaomi smartphone.

d. Distributors are expected to be able to improve service excellence to customers, especially relating to the delivery of information about Xiaomi smartphones, so that customers feel more comfortable and satisfied when buying a Xiaomi smartphone

3. Future researchers are advised to try to increase the number of samples, as well as adding a number of variables that also affect consumer satisfaction in using Xiaomi smartphone brands. These suggestions are important to encourage increased accuracy of research results in the future.

\section{REFERENCES}

[1] Kotler, Keller. Manajemen Pemasaran. Penerbit Erlangga. Jakarta. 2009

[2] Indonesia's Top Brand Index 2018-2019

[3] Kotler dan Keller. Manajemen Pemasaran. Jilid I. Edisi Ke 13. Jakarta: Erlangga. 2014

[4] Sheng, Tianxiang dan Liu, C. An empirical study on the effect of e-service quality on online customer satisfaction and loyalty. Nankai Business Review International Vol. 1 No. 3, 273-283. 2010.

[5] Maghnati, F., and KC Ling. 2013. Exploring the Relationship between Experiential Value and Usage Attitude towards Mobile Apps among the Smartphone Users. International Journal of Business and Management; Vol. 8

[6] Holbrook, MB 2000. The Millennial Consumer in the Texts of Our Times: Experience and Entertainment. Journal of Macro marketing, 20 (2), 178-192.

[7] Mathwick C, Malhotra N, Rigdon E . Experiential value: conceptualization, measurement and application in the catalogue and Internet shopping environment. Jurnal Retail., 77(1)hal: 39-56. 2001

[8] Batra, Rajeev dan Olli T. Ahtola. Measuring The Hedonic and Utilitarian Sources of 
Consumer Attitudes. Marketing Letters. Vol. 2[2]: 159-161. 1991

[9] Maghnati, F., KC Ling and A. Nasermoadeli. Exploring the Relationship between Experiential Marketing and Experiential Value in the Smartphone Industry. International Business Research. 5 (11), pp: 169-177. 2012.

[10] Vargo, SL, and Lusch, RF. Evaluating to a new dominant logic for marketing. Journal of Marketing, 68 (1), 1-17. 2004.

[11] Yang, ZY, and He, LY. Goal, Customer Experience and Purchase Intention in a Retail Context in China: An empirical study. African Journal of Business Management, 5 (16), 67386746. 2011.

[12] Yuan, YH. dan Wu, C. Relationship Among Experiential Marketing, Experiential Value, and Customer Satisfaction, Journal of Hospitality and Tourism Research 32(3): 387410. 2008

[13] Schmitt, BH. Experiential Marketing. Journal of Marketing Management, 15 (1), 53-67.1999

[14] Januar, TO and Diah, D. Analysis of the Effect of Experiental Marketing on Consumer Loyalty Through Satisfaction as Intervening Variables at Tator Cafe Surabaya Town Square. Journal of Marketing Management, Vol 1, No 2, 1-9. 2013

[15] Kertajaya, Hermawan. 2004. Marketing In Venus. Jakarta: Gramedia

[16] Chang, H. H., Wang, Y. H., dan Yang, W. Y., The Impact of e-Service Quality, Customer Satisfaction and Loyalty on e-Marketing: Moderating Effect of Perceived Value,Total Quality Management \& Business Excellence, Vol. 20, No. 4, pp. 423-443. 2009
[17] Larasati, Sri. Manajemen Sumber Daya Manusia. Yogyakarta: Deepublish. 2018

[18] Suprapto, Haddy. 2017. Metodologi Penelitian Untuk Karya Ilmiah. Yogyakarta: Gosyen Publishing. 2017

[19] Gowinda, H., Suprapti, W. The Effect of Experiential Marketing on Experiential Value on Smartphone Users in the City of Denpasar. Journal of Economics and Business, Udanaya University, Bali. 2013

[20] Wardani, Dewi Kusuma., dan Rumiyatun. Pengaruh Pengetahuan Wajib Pajak, Kesadaran Wajib Pajak, Sanski Pajak Kendaraan Bermotor, Dan Sistem Samsat Drive Thru Terhadap Kepatuhan Wajib Pajak Kendaraan Bermotor. Jurnal Akuntansi Vol. 5 No. 1 Juni 2017: 15-24. 2017.

[21] Rosanti et.al. Pengaruh Experiential Marketing dan Experiential Value terhadap Customer Satisfaction (survei pada mahasiswa fia bisnis 2013/2014 pengguna android samsung) jurnal administrasi bisnis (jab)|vol. 16 no. 1 november 2014| administrasibisnis. studentjournal. ub.ac.i. 2014

[22] Hair, Jr et.al. Multivariate Data Analysis (7th ed). United States : Pearson. 2010

[23] Ghozali, Imam. Aplikasi Analisis Multivariate dengan Program IBM SPSS 21 Update PLS Regresi. Semarang: Badan Penerbit Universitas Diponegoro. 2013.

[24] Ghozali, Imam. Structural Equation Modeling, Metode Alternatif dengan Partial Least Square (PLS). Edisi 4. Semarang : Badan Penerbit Universitas Diponegoro. 2014 